University of Nebraska - Lincoln

DigitalCommons@University of Nebraska - Lincoln

Publications from USDA-ARS / UNL Faculty

U.S. Department of Agriculture: Agricultural

Research Service, Lincoln, Nebraska

8-8-2019

\title{
Microsatellite markers in Spanish lime (Melicoccus bijugatus Jacq., Sapindaceae), a neglected Neotropical fruit crop
}

Jaime Martinez-Castillo

Centro de Investigacion Cientifica de Yucatan A.C., jmartinez@cicy.mx

Renee S. Arias

National Peanut Research Laboratory, renee.arias@usda.gov

Ruben $\mathrm{H}$. Andueza-Noh

CONACYT-Instituto Tecnológico de Conkal, r_andueza81@hotmail.com

Matilde M. Ortiz-Garcia

Centro de Investigacion Cientifica de Yucatan A.C., arimat@cicy.mx

Brian M. Irish

USDA-ARS, brian.irish@ars.usda.gov

See next page for additional authors

Follow this and additional works at: https://digitalcommons.unl.edu/usdaarsfacpub

Martinez-Castillo, Jaime; Arias, Renee S.; Andueza-Noh, Ruben H.; Ortiz-Garcia, Matilde M.; Irish, Brian M.; and Scheffler, Brian E., "Microsatellite markers in Spanish lime (Melicoccus bijugatus Jacq., Sapindaceae), a neglected Neotropical fruit crop" (2019). Publications from USDA-ARS / UNL Faculty. 2197.

https://digitalcommons.unl.edu/usdaarsfacpub/2197

This Article is brought to you for free and open access by the U.S. Department of Agriculture: Agricultural Research Service, Lincoln, Nebraska at DigitalCommons@University of Nebraska - Lincoln. It has been accepted for inclusion in Publications from USDA-ARS / UNL Faculty by an authorized administrator of DigitalCommons@University of Nebraska - Lincoln. 


\section{Authors}

Jaime Martinez-Castillo, Renee S. Arias, Ruben H. Andueza-Noh, Matilde M. Ortiz-Garcia, Brian M. Irish, and Brian E. Scheffler 


\title{
Microsatellite markers in Spanish lime (Melicoccus bijugatus Jacq., Sapindaceae), a neglected Neotropical fruit crop
}

\author{
Jaime Martínez-Castillo (1) Renée S. Arias • Rubén H. Andueza-Noh • \\ Matilde M. Ortiz-García • Brian M. Irish - Brian E. Scheffler
}

Received: 13 June 2019/Accepted: 30 July 2019/Published online: 8 August 2019

(C) Springer Nature B.V. 2019

This document is a U.S. government work and is not subject to copyright in the United States.

\begin{abstract}
Spanish lime (Melicoccus bijugatus Jacq.) is a Neotropical fruit tree cultivated, mainly, in orchards for self-consumption or local sale. The genus Melicoccus includes other nine species with edible fruits, some of these species are at risk of extinction. Like for the vast majority of tropical fruit trees, there is no information on the genetic diversity of Spanish lime and its related species, and this is mostly due to the lack of molecular markers. The objectives of this study were to present the first microsatellite markers developed for
\end{abstract}

Electronic supplementary material The online version of this article (https://doi.org/10.1007/s10722-019-00815-4) contains supplementary material, which is available to authorized users.

J. Martínez-Castillo ( $\square) \cdot$ M. M. Ortiz-García Unidad de Recursos Naturales, Centro de Investigación Científica de Yucatán A.C., Calle 43 No. 130, Colonia Chuburná de Hidalgo, CP 97200 Mérida, Yucatán, Mexico

e-mail: jmartinez@cicy.mx

M. M. Ortiz-García

e-mail: arimat@cicy.mx

\section{R. S. Arias}

National Peanut Research Laboratory, USDA-ARS, 1011

Forrester Dr. S.E., Dawson, GA 39842, USA

e-mail: renee.arias@ars.usda.gov

R. H. Andueza-Noh

CONACYT-Instituto Tecnológico de Conkal, Av.

Tecnológico S/N, 97345 Conkal, Yucatán, Mexico

e-mail: r_andueza81@ @otmail.com
Spanish lime, testing its usefulness on a sample of cultivated accessions, as well as its transferability to Huaya India (M. oliviformis). To do this, we performed high-throughput sequencing of microsatellite-enriched libraries of Spanish lime using Roche 454, assembled 9567 DNA contig sequences and identified 10,117 microsatellites. After screening 384 of those microsatellites on four DNA samples, 31 polymorphic markers were used to screen 25 accessions of Spanish lime and five of Huaya India collected in Yucatan, Mexico. Genetic diversity was low in Spanish lime ( $\left.A=20.61, H_{\mathrm{E}}=0.38\right)$ and similar for both sexes of this species. Neighbor-Joining and PCoA analyses clearly discriminated between the two Melicoccus

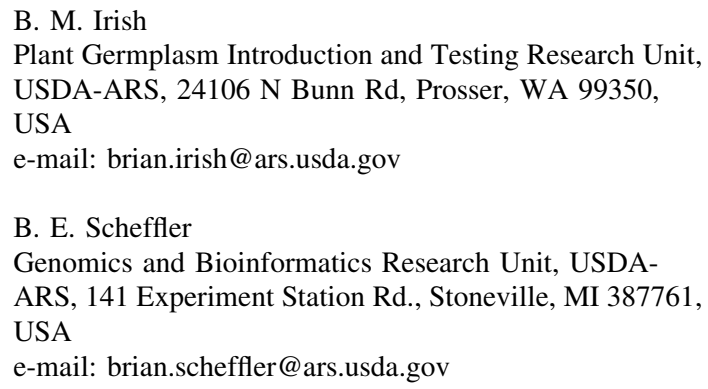


species studied. Nine of the markers showed unique alleles for Huaya India. The set of microsatellite markers developed has a great potential to generate information in relation to conservation genetics, improvement of elite cultivars and breeding programs for Spanish lime and related species.

Keywords Huaya India - Melicoccus oliviformis . Mexico $\cdot$ Yucatan state $\cdot$ SSR markers

\section{Introduction}

Tropical regions harbor a great diversity of fruit trees that for centuries have provided food and medicine to humankind (Normah et al. 2013; Paull and Duarte 2012). Usually, more than $90 \%$ of the fruit tree production in tropical areas is consumed locally as fresh fruit, though there has been a steady increase in demand of tropical fruits in world markets, as people become aware of their nutritional value and the health benefits associated to the consumption of these fruits (FAO 2010).

The genus Melicoccus (Sapindaceae) includes 10 species of Neotropical fruit trees. Its distribution range extends from the Yucatan peninsula in Mexico to South America, plus an isolated species in the Dominican Republic (Acevedo-Rodríguez 2003). Spanish lime (Melicoccus bijugatus Jacq.) and Huaya India (M. oliviformis Kunth.) are the most widely distributed species since their fruits, produced on female dioecious trees, are consumed in tropical areas around the world (Acevedo-Rodríguez 2003). Spanish lime is consumed as fresh fruit, mainly, but also as preserves, or in drinks and alcoholic beverages (Martin et al. 1987). Though some elite cultivars of Spanish lime have been generated, it is mainly cultivated in orchards of villages of South America, Central America, the Caribean and the Yucatan peninsula in Mexico (Morton 1987), and its cultivation has not reached international marketing levels such as lychee (Litchi chinensis Sonn.) and rambutan (Nephelium lappaceum L.), species of the Sapindaceae family but of Asian origin. Ethnobotanical information about Spanish lime includes the use of both seeds and pulp for medicinal purposes and multiple biologically active compounds have been found in the seed embryo, including flavonoids such as procianidine, epicatequine, catequine, epigalocatequine, naringenin and their derivatives phloretin, floridzine, quercetine, miricetin and resveratrol, all these compounds are used to treat diseases, e.g., parasite infections, diarrhea, fever and sore throat (Bystrom 2012). So, the medicinal value of Spanish lime could be as important as other Sapindaceae species (lychee, longan, rambutan) well known in Asia.

Currently, there are no studies on the genetic diversity of Spanish lime using co-dominant molecular markers, and the same is true for many tropical fruit trees. Though single-nucleotide polymorphisms markers (SNPs) are becoming increasingly popular given their abundance in genomes and the availability of high-throughput genotyping technologies, the microsatellites continue to be the most commonly used molecular markers. Because of their reproducibility, multi-allelic and co-dominant nature, microsatellites have multiple applications such as population genetics, gene mapping, performing marker assisted selection, and constructing linkage maps (Vieira et al. 2016). However, the development of microsatellite markers continues to be the limiting factor to study minor crops, such as tropical fruit trees. Our objectives were to develop the first microsatellite markers for Spanish lime, testing its usefulness on 25 cultivated accessions of Yucatan, Mexico, as well as its transferability to Huaya India.

\section{Materials and methods}

Two samples of Spanish lime from the collection at USDA-ARS Tropical Agriculture Research Station (TARS): accessions 'Sasa' (TARS 18206) and 'Doña Santos' (TARS 18219) were used to develop microsatellite markers for this species. DNA was extracted from leaves using DNeasy Plant Maxi kit (Qiagen, Valencia, CA). Microsatellite-enriched libraries were prepared according to Techen et al. (2010) with adaptations of the method for highthroughput sequencing as previously described in Arias et al. (2015). The libraries were sequenced in a Roche 454 GS-FLX (Roche, Branford, CT) using GS Titanium Sequencing kit XLR70 pico-titer plate (Roche, Branford, CT) for 200 cycles. Sequences were assembled with 454 gsAssembler version 2.0 (Roche, Branford, CT), microsatellite searched using SSRFinder (Sharapova et al. 2002), and primers were 
designed by Primer 3 (Rozen and Skaletsky 2000) using stringent conditions as described for other species (Arias et al. 2015).

Of the total markers obtained, a subset of 31 polymorphic markers (Table 1) were used for fingerprinting 30 Melicoccus accessions and test its usefulness in the species, as well as its transferability to Huaya India. To do this, 25 cultivated accessions of Spanish lime (15 female plants, 10 male plants) and five cultivated accessions of Huaya India were collected at flowering in Yucatan, Mexico (Table 2). Fingerprinting was performed as described by Arias et al. (2015) and briefly summarized here. An adaptor sequence $\left(5^{\prime}\right.$-CAGTTTTCCCAGTCACGAC-3') was added to the $5^{\prime}$ end of the forward primers. This forward primer sequence was then labelled with 6-carboxy-X-rhodamine (ROX) dye (IDT-Technologies, Coralville, IA) and used for amplification of

Table 1 Marker name, forward and reverse sequences, size range and allele number for 31 microsatellite markers screened on 30 accessions of Melicoccus spp. from Yucatan, Mexico

\begin{tabular}{|c|c|c|c|c|}
\hline Marker & Forward primer $5^{\prime} \rightarrow 3^{\prime}$ & Reverse primer $5^{\prime} \rightarrow 3^{\prime}$ & Size range & No \\
\hline MB0695a & TTAACTCAACTTTCCGACAGCAGC & TCTTGGTAGAGAAGTGAAGCCAGC & $165-211$ & 4 \\
\hline MB0743a & AAAGGAGACCAAACCCTAAATTGC & GTAATAGGGAATGATTCGGTGGTG & $105-292$ & 9 \\
\hline MB1842b & TCTCGTCTTCTTCTTCAATAGAACCAAC & CACTGGGATTTCTGGTGTACTTCC & $144-157$ & 3 \\
\hline MB1935a & TGATGATGAGGCGATAGAATATGG & AАCATCCСАAАCTTCTTCAАCACC & $130-524$ & 3 \\
\hline MB2129a & ACGATGTTTTTGCTGTTGACTTTG & TTTCATAAATGTTACGCATGTCACG & $105-165$ & 12 \\
\hline MB2361a & TTGCAAGTGCTAGAAAATCCATTG & TCCGTTGCTACATCTTCTTCTTCAC & $125-154$ & 4 \\
\hline MB2400a & CATTCAATGCAATAAGGAGAAGCTG & GTAATCAATGTGGGATGTGATTGG & $231-235$ & 2 \\
\hline MB2695a & GGCAAGCCAACTGTAGGATTTATG & ACAGGTTCCTCAACTGCTGTGAC & $169-172$ & 2 \\
\hline MB3227a & AGTCTGCAAAAGTCGCAAAAATG & GTTTGTAGCATGACTGGACCAATG & $147-279$ & 4 \\
\hline MB3400a & CCCTCATCATCGTCGTAGGTTATC & TTTCAGAAAGCGAAATGAATACAAAAG & $135-212$ & 4 \\
\hline MB3615a & GTGGTAGAAGGATCAGGGAGAGAG & CTCGTCATCTCTTTTCTCTCATGG & $139-231$ & 6 \\
\hline MB3630a & GGTTTTTCCAGGCTCCTAGATCG & TTCATAGCTATTTGTGACACCCCG & $131-484$ & 10 \\
\hline MB4008a & AATCCCACTCTTTGATCCAGTTTG & TTAAAACAACACAACCACAGCCAC & 128 & 1 \\
\hline MB4119a & AGGGAAGAAGGAATTGTGGAAAAG & TGTCGTCGTCTGCTTTCTCTATTG & $102-175$ & 5 \\
\hline MB4221a & GATACTTGGTGGAATAGAAGGGTGG & ССАСТGCАGCААТСТТАААСАСАС & $112-124$ & 3 \\
\hline MB4366a & TAGGCTGAATTTGGTGGAGAGAAG & TGGTGGGATGTACCAATCTTAATTC & $171-176$ & 2 \\
\hline MB4380a & ТСАААААТТТСААААССССТТСТТС & TCATCAGTAGGGTGGAACCTGAAC & 180-203 & 2 \\
\hline MB4821a & АТGTCАТСТТССТСТТСССТТТСС & CTATTGGAGTTGGAGTCACCGAAG & $106-184$ & 6 \\
\hline MB4847a & GAGGACAGAGAAGAGCAAGAGTGG & CACATTCGAACCTACTAACCAGCC & $166-193$ & 3 \\
\hline MB4915a & GTTAAGGTTTTCAATGTGGGAAAGG & GGCTCTCAAAATGACAGAAAACTCC & $129-178$ & 3 \\
\hline MB4947a & TGACTAAACCTTTCAGGCTGATCC & ATCGTCACCAACGAAAGTTGC & $156-179$ & 3 \\
\hline MB5054a & AGAGCGCCTAGAAGCAGAAGAAG & САТАСАСТTCСАCАTТCGTCCTTG & $140-149$ & 3 \\
\hline MB5123a & CCAGTTTACATAATGCAAGTTCCG & GCACATGAAAGCTAACCAAAACAC & $129-143$ & 5 \\
\hline$M B 5617 a$ & TTTGTGGATGGTTGACTTTTGAAG & ААCAACAAACATGCAAACAAAACC & $135-149$ & 4 \\
\hline MB5801a & TGTGATGGAGGGTTTTGTTTTCTC & AACGATATTCGTTTCTTGGCGTC & $168-194$ & 6 \\
\hline MB5932a & ААCTGAAACACAАCСТTТСАСТTСАТС & AGCATGTGGTCCGATAATCTTTTG & $101-116$ & 4 \\
\hline MB6181a & СССТСТТССТСТСССТАТСАGТТС & АCAGAACTTGAAAGCCTGATTTGAC & $96-106$ & 2 \\
\hline MB6289a & CTTGGTTCAATCTTGAAGTCCCAC & GAGTAAAAAGTAGAGATCAACTCCCACG & $100-116$ & 4 \\
\hline MB6464a & GGAGTTAGACAACCAAATAAATTAACCG & ATCCTCCACATCAAAAACCATTTC & 161-193 & 5 \\
\hline MB6579a & ACAAAACAGAGCTGACTCCAAACC & TTGGTGTTTCTGGTCATGAAAATG & $157-182$ & 6 \\
\hline$M B 7267 a$ & GTCAATACGTCCAAAATCCATGC & GCATTTGCTATGTTGCTTGAAGAG & $175-191$ & 4 \\
\hline
\end{tabular}

Size range: amplicons in base pairs; No.: number of alleles observed at each locus. Italic format indicate the nine markers that discriminated Melicoccus oliviformis 
Table 2 Data of the accessions of Melicoccus bijugatus and $M$. oliviformis collected in Yucatan, México

\begin{tabular}{|c|c|c|c|c|c|c|}
\hline Accession & Species & Village & Coordenates & & Female & Male \\
\hline ACAN_F & M. bijugatus & Acanceh & $20^{\circ} 48^{\prime} 46^{\prime \prime} \mathrm{N}$ & $89^{\circ} 27^{\prime} 13^{\prime \prime} \mathrm{O}$ & $X$ & \\
\hline BUCT_M & M. bijugatus & Buctzoz & $21^{\circ} 12^{\prime} 06^{\prime \prime} \mathrm{N}$ & $88^{\circ} 47^{\prime} 34^{\prime \prime} \mathrm{O}$ & & $\mathrm{X}$ \\
\hline BUCT_F & M. bijugatus & Buctzoz & $21^{\circ} 12^{\prime} 06^{\prime \prime} \mathrm{N}$ & $88^{\circ} 47^{\prime} 34^{\prime \prime} \mathrm{O}$ & $\mathrm{X}$ & \\
\hline BUCT_M & M. bijugatus & Buctzoz & $21^{\circ} 12^{\prime} 06^{\prime \prime} \mathrm{N}$ & $88^{\circ} 47^{\prime} 34^{\prime \prime} \mathrm{O}$ & & $\mathrm{X}$ \\
\hline CALO_F & M. bijugatus & Calotmul & $21^{\circ} 01^{\prime} 08^{\prime \prime} \mathrm{N}$ & $21^{\circ} 01^{\prime} 08^{\prime \prime} \mathrm{N}$ & $\mathrm{X}$ & \\
\hline CHOC_F & M. bijugatus & Chochola & $14^{\circ} 35^{\prime} 00^{\prime \prime} \mathrm{N}$ & $91^{\circ} 27^{\prime} 00^{\prime \prime} \mathrm{O}$ & $\mathrm{X}$ & \\
\hline CHUM_M & M. bijugatus & Chumayel & $20^{\circ} 25^{\prime} 42^{\prime \prime} \mathrm{N}$ & $89^{\circ} 18^{\prime} 04^{\prime \prime} \mathrm{O}$ & & $\mathrm{X}$ \\
\hline CONK_F & M. bijugatus & Conkal & $21^{\circ} 04^{\prime} 00^{\prime \prime} \mathrm{N}$ & $89^{\circ} 31^{\prime} 00^{\prime \prime} \mathrm{O}$ & $X$ & \\
\hline DZIT_F & M. bijugatus & Dzitas & $20^{\circ} 50^{\prime} 20^{\prime \prime} \mathrm{N}$ & $88^{\circ} 31^{\prime} 42^{\prime \prime} \mathrm{W}$ & $\mathrm{X}$ & \\
\hline ESPI_F & M. bijugatus & Espita & $21^{\circ} 00^{\prime} 46^{\prime \prime} \mathrm{N}$ & $88^{\circ} 18^{\prime} 17^{\prime \prime} \mathrm{O}$ & $\mathrm{X}$ & \\
\hline HALA_M & M. bijugatus & Halacho & $20^{\circ} 29^{\prime} 00^{\prime \prime} \mathrm{N}$ & $90^{\circ} 05^{\prime} 00^{\prime \prime} \mathrm{O}$ & & $\mathrm{X}$ \\
\hline KANT_F & M. bijugatus & Kantunil & $20^{\circ} 47^{\prime} 45^{\prime \prime} \mathrm{N}$ & $89^{\circ} 02^{\prime} 05^{\prime \prime} \mathrm{O}$ & $\mathrm{X}$ & \\
\hline KOPO_M & M. bijugatus & Kopoma & $20^{\circ} 38^{\prime} 52^{\prime \prime} \mathrm{N}$ & $89^{\circ} 53^{\prime} 55^{\prime \prime} \mathrm{O}$ & & $X$ \\
\hline MAN_M & M. bijugatus & Mani & $20^{\circ} 23^{\prime} 11^{\prime \prime} \mathrm{N}$ & $89^{\circ} 23^{\prime} 25^{\prime \prime} \mathrm{O}$ & & $\mathrm{X}$ \\
\hline MERI_M & M. bijugatus & Mérida & $20^{\circ} 58^{\prime} 04^{\prime \prime} \mathrm{N}$ & $89^{\circ} 37^{\prime} 18^{\prime \prime} \mathrm{O}$ & & $\mathrm{X}$ \\
\hline MOTU_F & M. bijugatus & Motul & $21^{\circ} 05^{\prime} 42^{\prime \prime} \mathrm{N}$ & $89^{\circ} 16^{\prime} 59^{\prime \prime} \mathrm{O}$ & $\mathrm{X}$ & \\
\hline OXKU_F & M. bijugatus & Oxkutzkab & $20^{\circ} 18^{\prime} 10^{\prime \prime} \mathrm{N}$ & $89^{\circ} 25^{\prime} 06^{\prime \prime} \mathrm{O}$ & $\mathrm{X}$ & \\
\hline OXKU_M & M. bijugatus & Oxkutzkab & $20^{\circ} 18^{\prime} 10^{\prime \prime} \mathrm{N}$ & $89^{\circ} 25^{\prime} 06^{\prime \prime} \mathrm{O}$ & & $\mathrm{X}$ \\
\hline PIS_M & M. bijugatus & Piste & $20^{\circ} 41^{\prime} 53^{\prime \prime} \mathrm{N}$ & $88^{\circ} 35^{\prime} 19^{\prime \prime} \mathrm{O}$ & & $\mathrm{X}$ \\
\hline SUCI_F & M. bijugatus & Sucila & $21^{\circ} 09^{\prime} 16^{\prime \prime} \mathrm{N}$ & $88^{\circ} 18^{\prime} 49^{\prime \prime} \mathrm{O}$ & $\mathrm{X}$ & \\
\hline TAME_F & M. bijugatus & Tahmek & $20^{\circ} 52^{\prime} 27^{\prime \prime} \mathrm{N}$ & $89^{\circ} 15^{\prime} 22^{\prime \prime} \mathrm{O}$ & $\mathrm{X}$ & \\
\hline TEKI_M & M. bijugatus & Tekit & $20^{\circ} 32^{\prime} 05^{\prime \prime} \mathrm{N}$ & $89^{\circ} 19^{\prime} 59^{\prime \prime} \mathrm{O}$ & & $\mathrm{X}$ \\
\hline TELCH_F & M. bijugatus & Telchaquillo & $20^{\circ} 38^{\prime} 45^{\prime \prime} \mathrm{N}$ & $89^{\circ} 27^{\prime} 51^{\prime \prime} \mathrm{O}$ & $X$ & \\
\hline TICO_F & M. bijugatus & Ticopo & $20^{\circ} 53^{\prime} 21^{\prime \prime} \mathrm{N}$ & $89^{\circ} 23^{\prime} 22^{\prime \prime} \mathrm{O}$ & $\mathrm{X}$ & \\
\hline MAXCA_F & M. bijugatus & Maxcanu & $20^{\circ} 34^{\prime} 59^{\prime \prime} \mathrm{N}$ & $90^{\circ} 00^{\prime} 03^{\prime \prime} \mathrm{O}$ & $\mathrm{X}$ & \\
\hline ACAN_F & M. oliviformis & Acanceh & $20^{\circ} 48^{\prime} 46^{\prime \prime} \mathrm{N}$ & $89^{\circ} 27^{\prime} 13^{\prime \prime} \mathrm{O}$ & $\mathrm{X}$ & \\
\hline MANI_F & M. oliviformis & Mani & $20^{\circ} 23^{\prime} 11^{\prime \prime} \mathrm{N}$ & $89^{\circ} 23^{\prime} 25^{\prime \prime} \mathrm{O}$ & $X$ & \\
\hline TELC_F & M. oliviformis & Telchaquillo & $20^{\circ} 38^{\prime} 45^{\prime \prime} \mathrm{N}$ & $89^{\circ} 27^{\prime} 51^{\prime \prime} \mathrm{O}$ & $\mathrm{X}$ & \\
\hline SUCI_M & M. oliviformis & Sucila & $21^{\circ} 09^{\prime} 16^{\prime \prime} \mathrm{N}$ & $88^{\circ} 18^{\prime} 49^{\prime \prime} \mathrm{O}$ & & $\mathrm{X}$ \\
\hline DZIT_F & M. oliviformis & Dzitas & $20^{\circ} 50^{\prime} 20^{\prime \prime} \mathrm{N}$ & $88^{\circ} 31^{\prime} 42^{\prime \prime} \mathrm{W}$ & & $\mathrm{X}$ \\
\hline
\end{tabular}

10-ng DNA in a $5 \mu \mathrm{L}$ reaction using Titanium Taq DNA Polymerase (Clontech, Mountain View, CA). Electropherograms were analyzed using the software GeneMapper 4.0 (Applied Biosystems, Foster City, CA). Basic Local Alignment Search Tool (BLAST) (Altschul et al. 1990) analysis, BLASTx was performed on the 31 microsatellite sequences.

Using the 31 polymorphic microsatellite markers before mentioned, genetic diversity was estimated in the 25 accessions of Spanish lime at the species and sex (female, male) levels using the average number of alleles per locus $(A)$, observed heterozygosity $\left(H_{\mathrm{O}}\right)$, expected heterozygosity $\left(H_{\mathrm{E}}\right)$ and fixation index $(\mathrm{F})$, calculated with GenAlex version 6.5
(Peakall and Smouse 2012). Finally, to test the transferability of these 31 markers to Huaya India, allele sizes observed in the electropherograms were converted to presence or absence of alleles (1: presence; 0: absence) and data were analyzed by Neighbor Joining (N-J) (Nei 1972) and Principal Coordinate Analysis (PCoA) (Gower 1966) using NTSYSpc v.2.2 (Rohlf 2008).

\section{Results and discussion}

Sequencing and assembly of the microsatellite-enriched libraries of Spanish lime resulted in 9567 
contigs (335 bp average length) containing repeats, a total of 3,203,629 nt. SSRFinder detected 10,117 SSRs on these contigs and the sequences were submitted to GenBank, NCBI with master accession number of KCYA00000000 and individual sequence numbers KCYA01000001-KCYA01009567. A total of 181 types of repeat motifs were found in microsatelliteenriched libraries of $M$. bijugatus, the most abundant are shown in Fig. 1. The count by motif length was: 20 motifs of $6 \mathrm{nt}, 27$ of $5 \mathrm{nt}, 62$ of $4 \mathrm{nt}, 56$ of $3 \mathrm{nt}, 12$ of 4 nt, and 4 of 1 nt. From the 10,117 repeats, Primer 3 designed 7551 high-stringency primer sets, from which 384 sets (Supplementary Table 1) were tested on four DNA accessions of Spanish lime: TARS 18206 and TARS 18219, 'Jose Pabon' (TARS 18218) and 'Melocoton' (TARS 18214). Results of the 384 primer sets tested using capillary electrophoresis are shown as allele sizes in Supplementary Table 2. In summary, 269 markers were monomorphic (70\%),

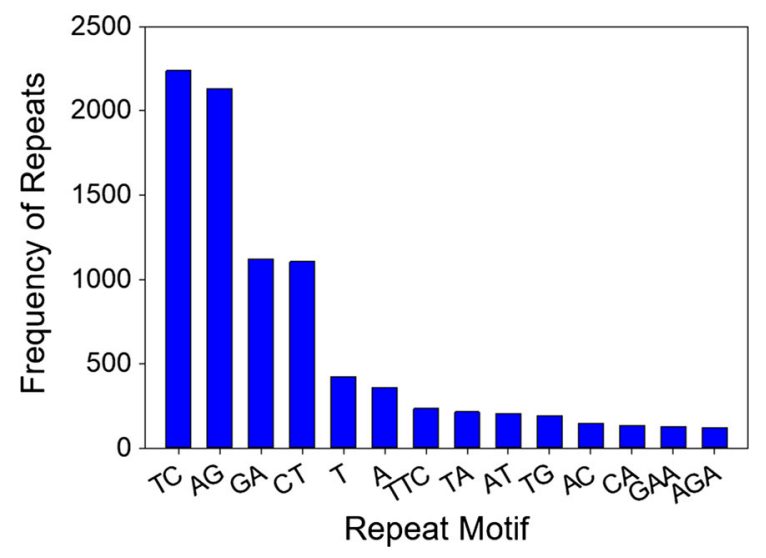

Fig. 1 Motifs and frequency of repeats detected in Spanish lime (Melicoccus bijugatus) microsatellite-enriched libraries
106 polymorphic (28\%), and nine (2\%) did not amplify in one or more samples. BLAST analysis showed significant hits to two transcription factors (MB4380 and MB4221) and one asparagine-tRNA ligase (MB4221) (Table 3). Since markers MB4380 and MB4221 differentiate both species, polymorphism directly linked to proteins (BLASTx) could be associated to different biological functions. Whereas in the case of asparagine-tRNA ligase, this enzyme participates in alanine and aspartate metabolism (Davies and Marshall 1972).

Spanish lime showed low genetic diversity at level species $\left(A=2.61, H_{\mathrm{E}}=0.38\right)$ (Table 4) when compared to that reported for lychee $\left(A=5.1, H_{\mathrm{E}}=0.53\right.$; Madhou et al. 2013). Also, we did not find differences in genetic diversity levels between male and female plants of Spanish lime. Factors that could explain our results are the relatively small sample size (25 accessions) used by us, or the existence of a founder effect as a result of the introduction of Spanish lime to Yucatan. There are no other publications on the genetic diversity of Melicoccus, and in general, there are limited studies on the genetic diversity of the family Sapindaceae using co-dominant markers such as microsatellites. Only one previous study had considered the genetic diversity of the genus Melicoccus, but that work was based on morphological and biochemical characteristics such as pulp $\mathrm{pH}$ and soluble solids, and was performed on cultivated accessions of Huaya India (Jiménez-Rojas et al. 2019).

Nine of the 31 markers tested showed unique alleles for Huaya India (Table 1), two markers (stvMEB4366a; stv-MEB6464a) had only null alleles on the five Huaya India, and one marker (stv-MEB4008a) was monomorphic on the 30 accessions tested. The

Table 3 Results of BLASTx of DNA sequences of the microsatellites used in this study

\begin{tabular}{llll}
\hline Markers & Lowest E-value & Accession (E-value) & Description \\
\hline MB2695 & $1.14 \mathrm{E}-46$ & XP_002314271 & Hypothetical protein SORBIDRAFT, Sorghum bicolor \\
MB0695 & $4.83 \mathrm{E}-09$ & XP_002513909 & Conserved hypothetical protein, Ricinus communis \\
MB1842 & $6.24 \mathrm{E}-15$ & XP_004290341 & GATA transcription factor 5-like, Fragaria vesca \\
MB3227 & $7.77 \mathrm{E}-06$ & XP_002302663 & Uncharacterized protein LOC7487284, Populus trichocarpa \\
MB4221 & $1.71 \mathrm{E}-19$ & XP_004249305 & Asparagine-tRNA ligase cytoplasmic, Solanum lycopersicum \\
MB4380 & $2.67 \mathrm{E}-26$ & XP_002319143 & NAC transcription factor 47, Populus trichocarpa \\
MB4947 & $2.25 \mathrm{E}-10$ & XP_004515508 & Uncharacterized protein LOC101503933, Cicer arietinum \\
MB4008 & $3.23 \mathrm{E}-04$ & XP_002445301 & Hypothetical protein SORBIDRAFT 07g008525, Sorghum bicolor \\
\hline
\end{tabular}


Table 4 Estimators of genetic diversity of 25 accessions of Spanish lime (Melicoccus bijugatus) cultivated in Yucatan, Mexico, using 31 microsatellite loci

\begin{tabular}{lllllll}
\hline Level & $\mathrm{N}$ & $A \pm \mathrm{SD}$ & $\mathrm{Ne} \pm \mathrm{SD}$ & $H_{\mathrm{O}} \pm \mathrm{SD}$ & $H_{\mathrm{E}} \pm \mathrm{SD}$ & $\mathrm{F} \pm \mathrm{SD}$ \\
\hline Species & 25 & $2.61 \pm 0.24$ & $1.89 \pm 0.12$ & $0.39 \pm 0.05$ & $0.38 \pm 0.04$ & $0.03 \pm 0.06$ \\
Female & 15 & $2.52 \pm 0.02$ & $1.84 \pm 0.13$ & $0.39 \pm 0.05$ & $0.37 \pm 0.04$ & $0.05 \pm 0.06$ \\
Male & 10 & $2.36 \pm 0.18$ & $1.72 \pm 0.10$ & $0.38 \pm 0.05$ & $0.36 \pm 0.04$ & $0.08 \pm 0.06$
\end{tabular}

$\mathrm{N}$, sample size; $A$, average number of alleles per locus; Ne, average number of effective alleles; $H_{\mathrm{O}}$, observed heterozygosity; $H_{\mathrm{E}}$, expected heterozygosity; F, fixation index; SD, standard deviation

Fig. 2 Neighbor Joining analysis of 25 accessions of Spanish lime (Melicoccus bijugatus) and five accessions of $M$. oliviformis from Yucatan, Mexico, using 31 microsatellite loci. Accession names followed by_F: female;_M: male

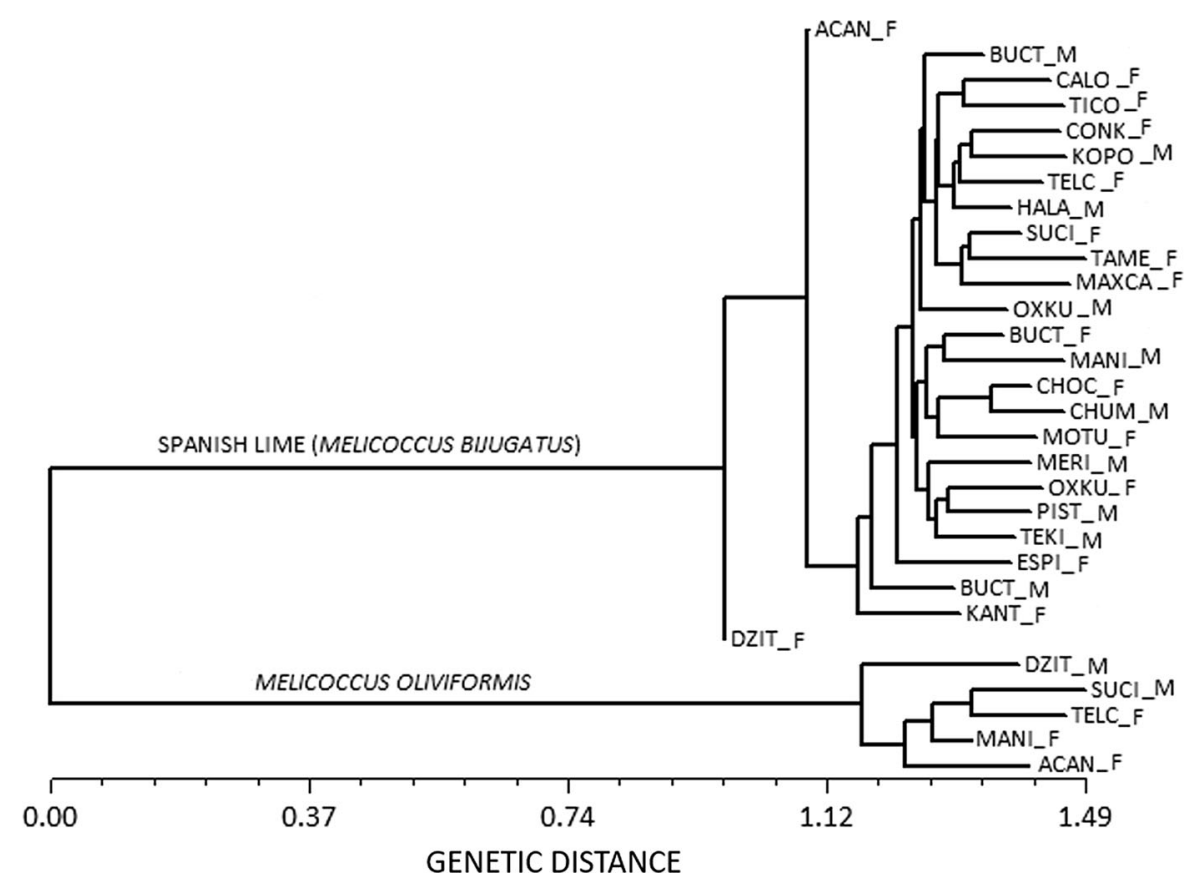

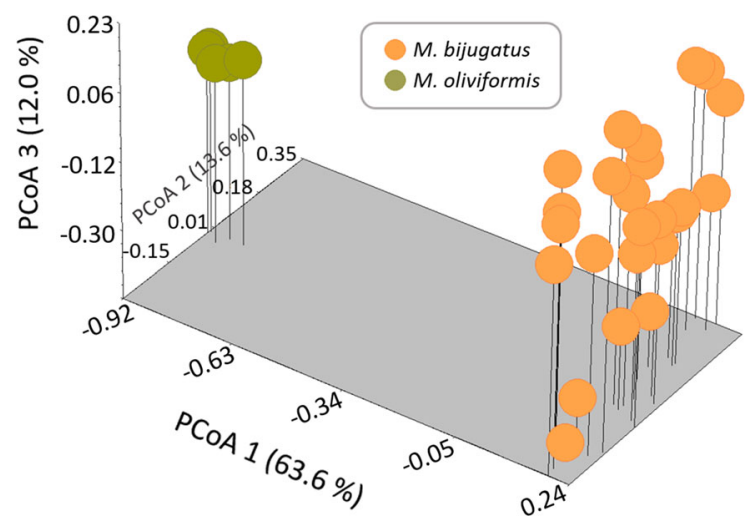

Fig. 3 Principal coordinate analysis (PCoA) of 25 accessions of Spanish lime (Melicoccus bijugatus) and five accessions of Huaya India (M. oliviformis) collected in the Yucatan peninsula, Mexico, using 31 SSR loci
N-J (Fig. 2) and the PCoA (Fig. 3) analyses clearly discriminated between Spanish lime and Huaya India, but not between male and female plants of Spanish lime. The accessions of Spanish lime did not indicate association to their geographic origin, maybe because this species is not native of Mexico (Martin et al. 1987; Acevedo-Rodríguez 2003). A similar pattern was observed in M. oliviformis, a species native of Mexico, maybe for the low number (5) of individuals included in this study.

\section{Conclusions}

Microsatellite markers developed here showed highquality amplification in Spanish lime and 
transferability to Huaya India. These markers could potentially be expanded to the other species of Meliccocus and even Talisia, a closely genus native of the Amazon with 52 species (Acevedo-Rodríguez 2003). Limited sample collections of Melicoccus and Talisia species indicate they could be at risk of extinction, including $M$. jimenezzi, a Dominican Republic endemic restricted to a small population (Acevedo-Rodríguez 2003). There are limited genetic diversity studies in Sapindaceae, and none in Melicoccus. This prevents knowing the state of conservation of Melicoccus and how this information could impact the preservation of genetic resources that are vital for people in the tropics. The markers reported here will help generate information in relation to conservation genetics, improvement of elite cultivars and breeding programs.

Acknowledgements This work was supported by USDAARS Project 6044-21000-004-00D. The authors would like to thank Mary V. Duke, Linda L. Ballard, Sheron A. Simpson, and Xiaofen F. Liu, for DNA sequencing, sequence assembly and screening microsatellite markers.

\section{Compliance with ethical standards}

Conflict of interest The authors declare that they have no conflict of interest.

\section{References}

Acevedo-Rodríguez P (2003) Meliococceae (Sapindaceae): Melicoccus and Talisia. Flora Neotropical monograph. Botanical Garden Bronx, New York

Altschul SF, Gish W, Myers EW, Lipman DJ (1990) Basic local alignment search tool. J Mol Biol 215:403-410. https://doi. org/10.1016/S0022-2836(05)80360-2

Arias RS, Martínez-Castillo J, Sobolev VS, Blancarte-Jasso NH, Simpson SA, Ballard LL, Duke MV, Liu XF, Irish BM, Scheffler BE (2015) Development of a large set of microsatellite markers in zapote mamey (Pouteria sapota (Jacq.) H.E. Moore \& Stearn) and their potential use in the study of the species. Molecules 20:11400-11417. https:// doi.org/10.3390/molecules200611400

Bystrom LM (2012) The potential health effects of Melicoccus bijugatus Jacq. fruits: Phytochemical, chemotaxonomic and ethnobotanical investigations. Fitoterapia 83(2):266-271. https://doi.org/10.1016/j.fitote.2011.11. 018

Davies MR, Marshall RD (1972) Partial purification of L-asparaginyl-tRNA synthetase from rabbit liver. Biochem Biophys Res Commun 47:1386-1395. https://doi.org/10. 1016/0006-291X(72)90226-4
FAO (2010) Statistical yearbook. http://www.fao.org/fileadmin/ templates/ess/ess_test_folder/publications/yearbook_ 2010/c11.xls. Accessed 20 March 2019

Gower JC (1966) Some distance properties of latent root and vector methods used in multivariate analysis. Biom Trust 53:325-338. https://doi.org/10.1093/biomet/53.3-4.325

Jiménez-Rojas MI, Martínez-Castillo J, Potter D, Dzib GR, Ballina-Gómez HS, Latournerie-Moreno L, Andueza-Noh RH (2019) Morphological diversity of Huaya India fruits (Melicoccus oliviformis Kunth) in the Maya lowlands. Genet Res Crop Evol 66:513-522. https://doi.org/10.1007/ s10722-018-00731-z

Madhou M, Normand F, Bahorun T, Hormaza JI (2013) Fingerprinting and analysis of genetic diversity of litchi (Litchi chinensis Sonn.) accessions from different germplasm collections using microsatellite markers. Tree Genet Genomes 9:387-396. https://doi.org/10.1007/s11295-0120560-1

Martin FW, Campbell CW, Ruberté RM (1987) Perennial edible fruits of the tropics: an inventory. Agriculture handbook no. 642. Department of Agriculture, Washington, D.C.

Morton JF (1987) Mamoncillo. In: Morton JF (ed) Fruits of warm climates. Florida, Miami

Nei M (1972) Genetic distance between populations. Am Nat 106:283-292. https://doi.org/10.1086/282771

Normah MN, Malik SK, Chaudhury R, Salma I, Makeen MA (2013) Conservation of tropical fruit genetic resources. In: Normah M, Chin H, Reed B (eds) Conservation of tropical plant species. Springer, New York

Paull RE, Duarte O (2012) Tropical fruits. CAB International, London

Peakall R, Smouse PE (2012) GenAlEx 6.5: genetic analysis in Excel. Population genetic software for teaching and research - an update. Bioinformatics 28:2537-2539. https://doi.org/10.1093/bioinformatics/bts460

Rohlf FJ (2008) NTSYS-pc. Numerical taxonomy system version 2.2. Exeter Publishing, Ltd., Setauket

Rozen S, Skaletsky H (2000) Bioinformatics methods and protocols in the series methods in molecular biology. Humana Press, Totowa

Sharapova N, McMullen MD, Schultz L, Schoroeder S, SánchezVilleda H, Gardiner J, Bergstrom D, Houchins K, MeliaHancock S, Musket T, Duru N, Polacco M, Edwards K, Ruff T, Register JC, Brouwer C, Thompson R, Velasco R, Chin E, Lee M, Woodman-Clikeman W, Long MJ, Liscum E, Cone K, Davis G, Coe EH (2002) Development and mapping of SSR markers for maize. Plant Mol Biol 48:463-481. https://doi.org/10.1093/bioinformatics/bts460

Techen NR, Arias RS, Glynn NC, Pan Z, Khan I, Scheffler BE (2010) Optimized construction of microsatellite-enriched libraries. Mol Ecol Resour 10:508-515. https://doi.org/10. 1111/j.1755-0998.2009.02802.x

Vieira ML, Santini L, Diniz AL, Munhoz C (2016) Microsatellite markers: what they mean and why they are so useful. Genet Mol Biol 39:312-328. https://doi.org/10. 1590/1678-4685-GMB-2016-0027

Publisher's Note Springer Nature remains neutral with regard to jurisdictional claims in published maps and institutional affiliations. 